\title{
Juvenile coral population dynamics track rising seawater temperature on a Caribbean reef
}

\author{
Peter J. Edmunds* \\ Department of Biology, California State University, Northridge, California 91330-8303, USA
}

\begin{abstract}
There is now widespread consensus that climate change-related increases in seawater temperature have become a leading cause of coral mortality by bleaching. However, despite widely reported and geographically extensive coral-bleaching episodes, little is known about the less conspicuous demographic consequences of elevated temperature for coral populations. Here, I use $12 \mathrm{yr}$ of daily temperature records and $8 \mathrm{yr}$ of annual surveys of juvenile corals ( $\leq 40 \mathrm{~mm}$ diameter, a size range that includes recruits) from the US Virgin Islands to demonstrate the subtle effects of an unusually rapid increase in seawater temperature $\left(0.06^{\circ} \mathrm{C}\right.$ per year since 1989$)$ on coral community structure in shallow water (5 to $9 \mathrm{~m}$ depth). The analysis reveals that the density of juvenile corals is correlated positively with mean seawater temperature, but concurrently, in warm years, juvenile corals tend to grow slowly and appear to die faster, in a pattern leading to changes in relative generic abundance. Although perturbations such as these appear minor against the backdrop of widespread reef degradation, summation of these subtle effects could result in major changes, with far-reaching ecological consequences for the survival of coral reefs.
\end{abstract}

KEY WORDS: Coral $\cdot$ Recruitment $\cdot$ Seawater temperature $\cdot$ Caribbean

\section{INTRODUCTION}

There is strong evidence that global warming has increased the global average surface temperature by $0.6^{\circ} \mathrm{C}$ over the last century (IPCC 2001), and has driven ecological changes in polar to tropical latitudes and mountain to subtidal environments (Walther et al. 2002). Coral reefs are one ecosystem that appears to be particularly sensitive to these effects, and already many corals have been killed by rising seawater temperature that has caused severe coral bleaching (Hoegh-Guldberg 1999, Fitt et al. 2001, Knowlton 2001). Surprisingly, despite the high frequency and extent of bleaching episodes (Hoegh-Guldberg 1999, Knowlton 2001), almost nothing is known regarding the demographic responses of coral communities to gradually increasing seawater temperature.

Recently, there has been much attention paid to the catastrophic effects of global climate change (HoeghGuldberg 1999, Scheffer et al. 2001, Walther et al. 2002), but the effects on ecosystem function, and the distribution, abundance and phenology of organisms are less well known (Scheffer et al. 2001, Walther et al. 2002). Modifications of these biotic phenomena can have far-reaching effects, but their immediate results often pale into insignificance in the face of the more striking biological impacts of global warming. The paucity of empirical studies linking global climate change to community dynamics present a challenge to recognize the early signs of change in ecosystem structure or function, and to forecast the trajectories of community dynamics under global climate-change scenarios. In tropical marine environments, however, a few studies suggest that rising seawater temperatures, short of those causing catastrophic coral mortality (Hoegh-Guldberg 1999, Knowlton 2001), will cause substantial changes in coral community structure. For example, changing frequencies of El Niño-Southern Oscillations (ENSO) events have been predicted to alter the colony size-structure of Gardinoseris planulata populations at Uva Island (Panama: Fong \& Glynn 2000), and bleaching in 1998 enriched the coral com- 
munity at Sesoka Island (Japan) with massive and encrusting species by preferentially killing finely branched corals (Loya et al. 2001), while along the Kenyan coast it killed Acropora spp. colonies and paved the way for recruitment by the genera Pocillopora and Porites (Tamelander 2002). Changes like these can have important consequences, for instance by altering population growth rates through changes in the abundance of the most fecund colonies (i.e. the biggest: Harrison \& Wallace 1990) and reducing reef accretion by favoring massive corals that grow slowly (Buddemeier \& Kinzie 1976).

St. John, US Virgin Islands, provides a good location to study the effects of climate change on Caribbean reefs, because most of its nearshore marine environments are protected from direct anthropogenic influence (Rogers \& Beets 2001). Therefore, local reef dynamics are more likely to be mediated by local natural events (such as periodic recruitment pulses and intraspecific competition) and large-scale phenomena (such as hurricanes and global warming) than pointsource anthropogenic effects. On the south coast of St. John, the fringing reefs in shallow water $(<6 \mathrm{~m}$ depth) typically consist of thin communities encrusting granite substratum (Witman 1992, Edmunds 2000), with patches of scleractinian coral ( $\leq 10 \%$ cover) and large amounts of algal turf and crustose coralline algae (Edmunds 2000). In deeper water, coral cover is variable, but reaches 10 to $40 \%$ where dense stands of Montastraea annularis are found (Rogers \& Miller 2001, Edmunds 2002). Within Great Lameshur Bay and its environs (see Fig. 1), coral reefs have been monitored since the 1980s (Rogers \& Beets 2001, Edmunds 2002), with continuous records of seawater temperature beginning in 1989. The present study was designed to describe variation in seawater temperature and juvenile coral populations over 8 to $12 \mathrm{yr}$, and to test the hypothesis that these abiotic and biotic factors are coupled. To achieve this goal, first I describe interannual variation in seawater temperature and the density of juvenile corals, and second test for a statistically significant correlation between the two. Having demonstrated that the density of juvenile corals is related to seawater temperature, I examine the potential roles of juvenile growth and mortality in driving the relationship. Finally, I explore the changes in relative abundance of juvenile coral genera in order to gain insight into the possible consequences of sublethal changes in seawater temperature for coral community structure. Although the statistical association between random variables cannot demonstrate a cause-and-effect relationship, it can provide clues to important functional relationships that can be investigated further with manipulative experimentation. The emphasis here on juvenile corals (rather than adult corals) reflects the demographic importance of this lifehistory stage, the potential responsiveness of their population dynamics to abiotic factors as a result of the normally rapid turnover of individual colonies (Bak \& Engel 1979, Edmunds 2000), and the unusual ease in St. John of quantifying small corals on the large amounts of relatively smooth granite substratum in shallow water.

\section{MATERIALS AND METHODS}

Study site. Research was completed on the shallow reefs along the south coast of St. John between Cabritte Horn and White Point. These 2 headlands encompass $4.5 \mathrm{~km}$ of coastline in 3 bays that are within the VI National Park and Biosphere Reserve. Seawater temperature was recorded continuously at 9 to $11 \mathrm{~m}$ depth off Yawzi Point (separating 2 of the bays), and juvenile corals were censused at 6 sites located haphazardly (Fig. 1). Each site consists of a permanently marked $40 \mathrm{~m}$ transect at $5 \mathrm{~m}$ ( 5 sites) or $9 \mathrm{~m}$ (1 site) depth, and all are dominated by hard substrata catego-

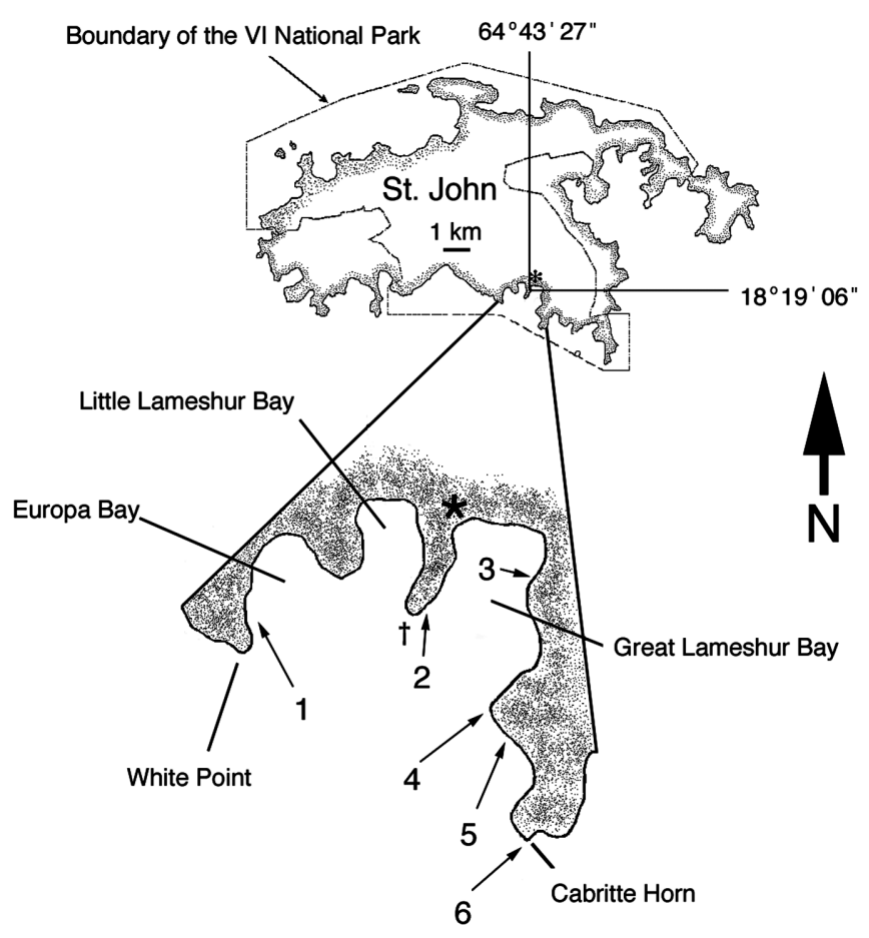

Fig. 1. Map of St. John, US Virgin Islands, showing locations of study sites: 1: White Point; 2: East Yawzi Point; 3: Donkey Bite; 4: West Tektite; 5: East Tektite; 6: Cabritte Horn. Sample sites were selected haphazardly, where the coast was accessible by a small boat based at the Virgin Islands Ecological Resource Station $(*)$, and are within the VI National Park and Biosphere Reserve. Seawater temperature was recorded at 9 to $11 \mathrm{~m}$ depth off Yawzi Point (†) 
rized as crustose coralline algae, algal turf or bare space. Patches of sand were not found along the transects at 3 of the sites, and were present in only a few quadrats at the remaining sites (the community structure is broadly similar to that described by Edmunds [2002] for nearby areas at 7 to $9 \mathrm{~m}$ depth). Surveys were completed in May 1995 (2 sites) and 1996 (5 sites), July 1999, 2000 and 2001 (6 sites), and August 1994 (5 sites), 1997 and 1998 (6 sites).

Seawater temperature. Starting in 1989, seawater temperature was recorded with a Ryan Industries thermistor $\left( \pm 0.3^{\circ} \mathrm{C}\right.$ accuracy) as part of the National Park Service Reef Assessment Program. This thermistor was located at $11 \mathrm{~m}$ depth and recorded temperature from January 1989 to April 1997 and November 1997 to August 1999. The May to October 1997 gap in the record was caused by equipment problems, and was filled (June 1997 to October 1997) with data collected with an Optic Stowaway $\left( \pm 0.2^{\circ} \mathrm{C}\right.$ accuracy, Onset ${ }^{\mathrm{TM}}$ Corporation) placed at $9 \mathrm{~m}$ depth. Temperature records for May 1997 were obtained from a dive computer. The Optic Stowaway was also used for temperature records for August 1999 to August 2001. Daily temperature records were used to calculate monthly averages and to determine the number of thermally extreme days each year. Days were categorized as 'hot' when the mean daily temperature exceeded the local coral bleaching threshold of $29.3^{\circ} \mathrm{C}$, as determined by the United States National Oceanic and Atmospheric Administrations, National Environmental Satellite Data and Information Service (NOAA/ NESDIS; http://orbit-net.nesdis.noaa.gov/orad/sub/sst_ series_virginpath.html); 'cold' days were recorded when the mean daily temperature was at or below an arbitrary value of $26.0^{\circ} \mathrm{C}$ (the 15th percentile of the daily temperatures).

Juvenile coral surveys. Juvenile corals were defined as corals between $\approx 2 \mathrm{~mm}$ ( 1 polyp) and $\leq 40 \mathrm{~mm}$ diameter, and therefore included both recruits (sensu stricto) and very young corals, and were censused using $0.25 \mathrm{~m}^{2}$ quadrats $\left(\mathrm{n}=40\right.$ per site $\left.\mathrm{yr}^{-1}\right)$ positioned randomly along the transect line at each site. Quadrats were re-randomized for each survey. Juvenile corals were located by inspection of the substratum, parting algae and brushing away sediments where necessary, and were identified to genus. The design of this sampling protocol was driven by the necessities of completing the surveys during a single annual visit, counting sufficiently large numbers of corals to allow parametric statistics to be used in their analyses (the low density of coral recruits, i.e. spat, made them intractable to a separate analysis), and the difficulty of identifying small corals on natural substrata in situ (in most cases, the smallest corals could not be identified reliably to species). The principle limitations of this design are that it cannot detect recruits that both arrive and die in the year preceding sampling, and creates the potential of counting the same juvenile corals in successive surveys. Moreover, the juvenile coral sizeclass and generic resolution make it impossible to distinguish recruitment from post-settlement events, or to resolve population dynamics that differ among species.

Starting in 1996, the mortality and growth of juvenile corals was determined by tagging randomly selected corals from multiple genera and determining their size and condition (i.e. alive or dead) 1 yr later. Colonies were scored as dead if they were dead in their growth position or missing from the tagged location, and size was determined using calipers $( \pm 0.1 \mathrm{~mm})$, and calculated as the mean of the 2 major diameters of the basal portion of each colony. The growth of the tagged colonies was assessed as the change in mean diameter between sampling periods. Sample sizes for the tagging experiment varied from year to year, depending on the number of corals that died, the number of tags that could not be relocated, and the number of new corals tagged each year.

Statistical analyses. Least-squares linear regression was used to test the relationship between seawater temperature and time, and a $\chi^{2}$-contingency table was used to compare the number of thermally extreme days over 3 periods of $4 \mathrm{yr}$ duration each; years were pooled to achieve high expected cell frequencies (Zar 1999). The density of juvenile corals was compared among years with a 1-way ANOVA on square-root $(x+$ 0.5 )-transformed data, and post hoc comparisons were completed with a Tukey procedure. Growth rates were compared among years using ANCOVA, with initial size as a covariate and year as the fixed factor; post hoc comparisons were completed with a Tukey procedure. Mortality rates (i.e. the number of corals categorized as alive or dead) and the relative abundance of juvenile coral genera were compared among times using $\chi^{2}$ contingency tables. Tests of a relationship between seawater temperature and the population dynamics of juvenile corals were carried out with Pearson correlations. The assumptions of the parametric statistical procedures (i.e. ANOVA and ANCOVA) were tested with graphical analyses of the residuals, and juvenile corals were pooled by taxon for the analysis of density, growth and mortality. All analyses were completed using SYSTAT 9.0 software.

\section{RESULTS}

On the south coast of St. John, in Great Lameshur Bay, yearly mean monthly seawater temperature has increased significantly between 1989 and $2000(F=$ 7.941, df $=1,10, p=0.018$ ), with an annual rate of 
increase (i.e. based on the slope of the regression of temperature on year) equivalent to $0.06^{\circ} \mathrm{C} \mathrm{yr}^{-1}$ (Fig. 2A). In addition to the rising seawater temperature, the number of thermally extreme days has changed significantly $\left(\chi^{2}=124.73, \mathrm{df}=2, \mathrm{p}<0.001\right)$,

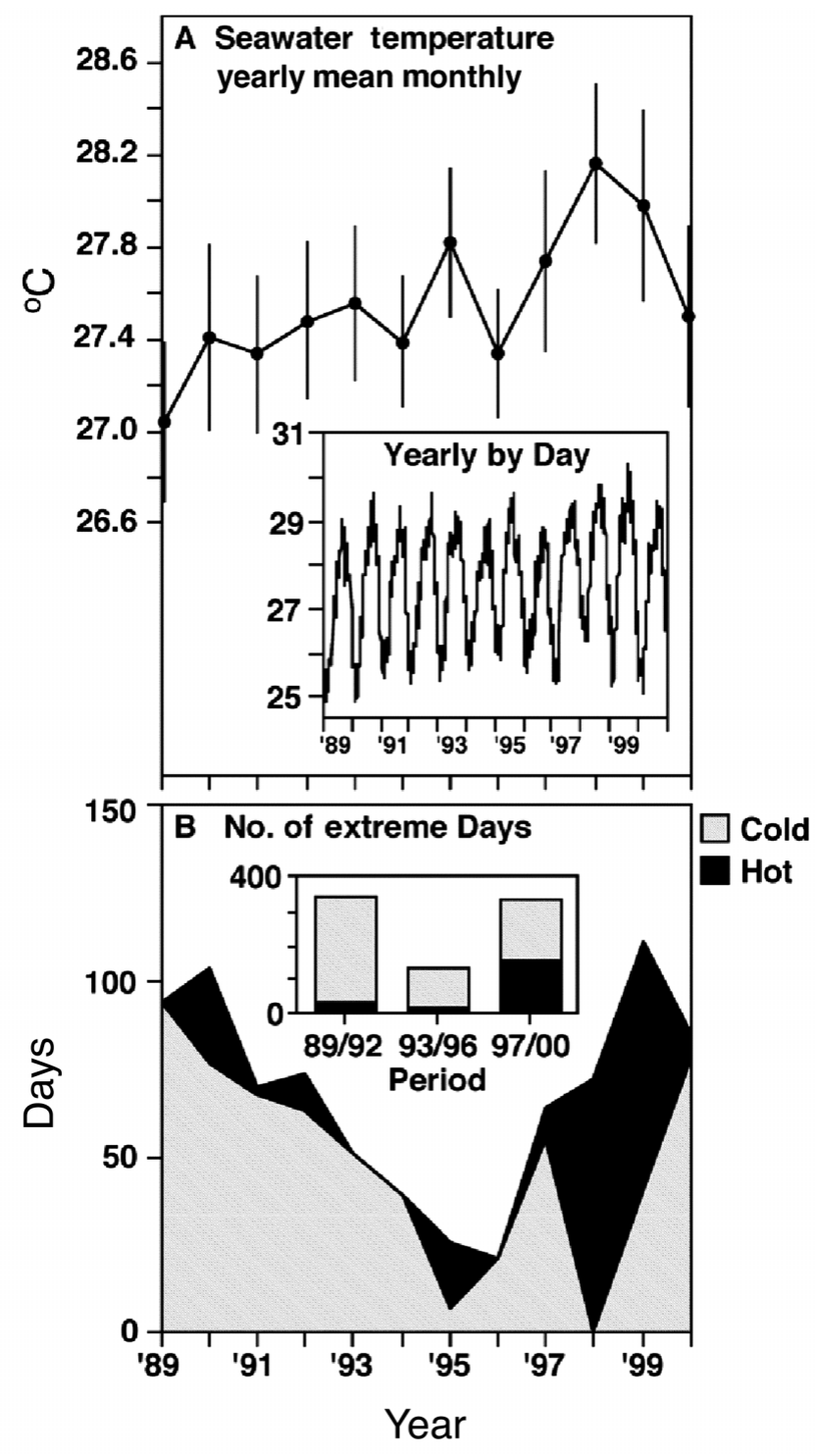

Fig. 2. Line and area plots of seawater temperature and number of thermally extreme days recorded each year. (A) Yearly mean monthly temperature (mean $\pm \mathrm{SE}, \mathrm{n}=12$ ); based on these values, temperature increased significantly between

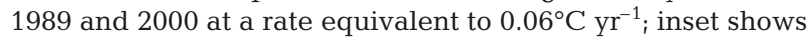
daily values over same period $(\mathrm{n}=4230)$. (B) Number of days per year that were categorized as hot (i.e. exceeding local bleaching threshold of $29.3^{\circ} \mathrm{C}_{i}$ (see http://orbit-net. nesdis.noaa.gov/orad/sub/sst_series_virginpath.html) or cold $\left(\leq 26.0^{\circ} \mathrm{C}\right)$; inset shows number of hot and cold days during first, middle, and final thirds of study. Relative number of hot and cold days varied significantly among these periods, largely because hot days were more common from 1997 to 2000, than from 1993 to 1996 or from 1989 to 1992 with hot days (i.e. $>29.3^{\circ} \mathrm{C}$ ) becoming more common, and cold days (i.e. $\leq 26.0^{\circ} \mathrm{C}$ ) becoming rare (Fig. 2B).

During this study, at least 16 genera of juvenile corals were found, but $96 \%$ of the colonies ( $\mathrm{n}=1598$ ) were Porites, Favia, Agaricia or Siderastrea. Mean densities of juvenile corals differed significantly among years $(F=5.671$, df $=7,1548, \mathrm{p}<0.001)$, and were correlated significantly and positively $(r=0.722$, $\mathrm{df}=6, \mathrm{p}=0.043$ ) with yearly mean monthly seawater temperatures in the 12 mo preceding each sampling (Fig. 3A). The juvenile corals tagged during this study had an average diameter of $16.3 \pm 0.3 \mathrm{~mm}( \pm \mathrm{SE}, \mathrm{n}=$ 467 ), and 22 to $46 \%$ of them died each year (Fig. 3). Juvenile coral mortality rates varied significantly among years $\left(\chi^{2}=14.560\right.$, df $\left.=4, \mathrm{p}=0.006\right)$ and, although they increased with temperature (Fig. 3C), this trend was not statistically significant $(\mathrm{r}=0.789$, $\mathrm{df}=3, \mathrm{p}=0.115$ ). The growth rates (i.e. change in diameter) of juvenile corals ranged from $-23.0 \mathrm{~mm} \mathrm{yr}^{-1}$

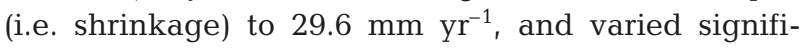
cantly among years $(F=4.275$, df $=4,461$, p $=0.002)$; the slopes of the regressions of growth on size did not vary significantly among years $(F=1.499$, df $=4,457$, $\mathrm{p}=0.201$ ). The fastest growth occurred in 2001, and the slowest in the year following the severe ENSO episode of 1998, when coral bleaching occurred in the Caribbean (Warner et al. 1999) (Fig. 3B). Mean annual growth rates were correlated significantly and positively ( $\mathrm{r}=0.950$, $\mathrm{df}=3, \mathrm{p}=0.013$ ) with the number of cold days in the 12 to 24 mo period prior to sampling (Fig. 3), but were not correlated significantly with the number of cold days $(p>0.05)$, or the yearly mean monthly temperatures ( $p>0.05$ ) over the year immediately preceding growth determination (i.e. 0 to $12 \mathrm{mo}$ prior to sampling). These trends remained unchanged when growth was recalculated using only values $\geq 0 \mathrm{~mm} \mathrm{yr}^{-1}$, most notably with a significant and positive relationship with the number of cold days in the 12 to 24 mo period prior to sampling $(\mathrm{r}=0.941$, $\mathrm{df}=3, \mathrm{p}<$ 0.02). Juvenile density, growth and mortality were not correlated significantly with the number of hot days in the year preceding sampling $(p>0.20)$ or 12 to 24 mo earlier $(\mathrm{p}>0.10)$.

For the 8 yr that juvenile corals were censused, the population was dominated ( $\geq 96 \%$ of the corals) by 4 genera characterized by brooding species (only Siderastrea siderea broadcasts, but this accounted for $<21 \%$ of the Siderastrea). The relative abundance of these genera varied significantly over the study period $\left(\chi^{2}=209.014\right.$, df $\left.=8, \mathrm{p}<0.001\right)$, largely because Siderastrea was more abundant, and Porites less abundant, in the final third of the study, and Favia was more abundant in the middle third of the study (Fig. 4). These intervals span a period of increasing seawater temperature, and represent 3 yr (1994 to 1996) with 

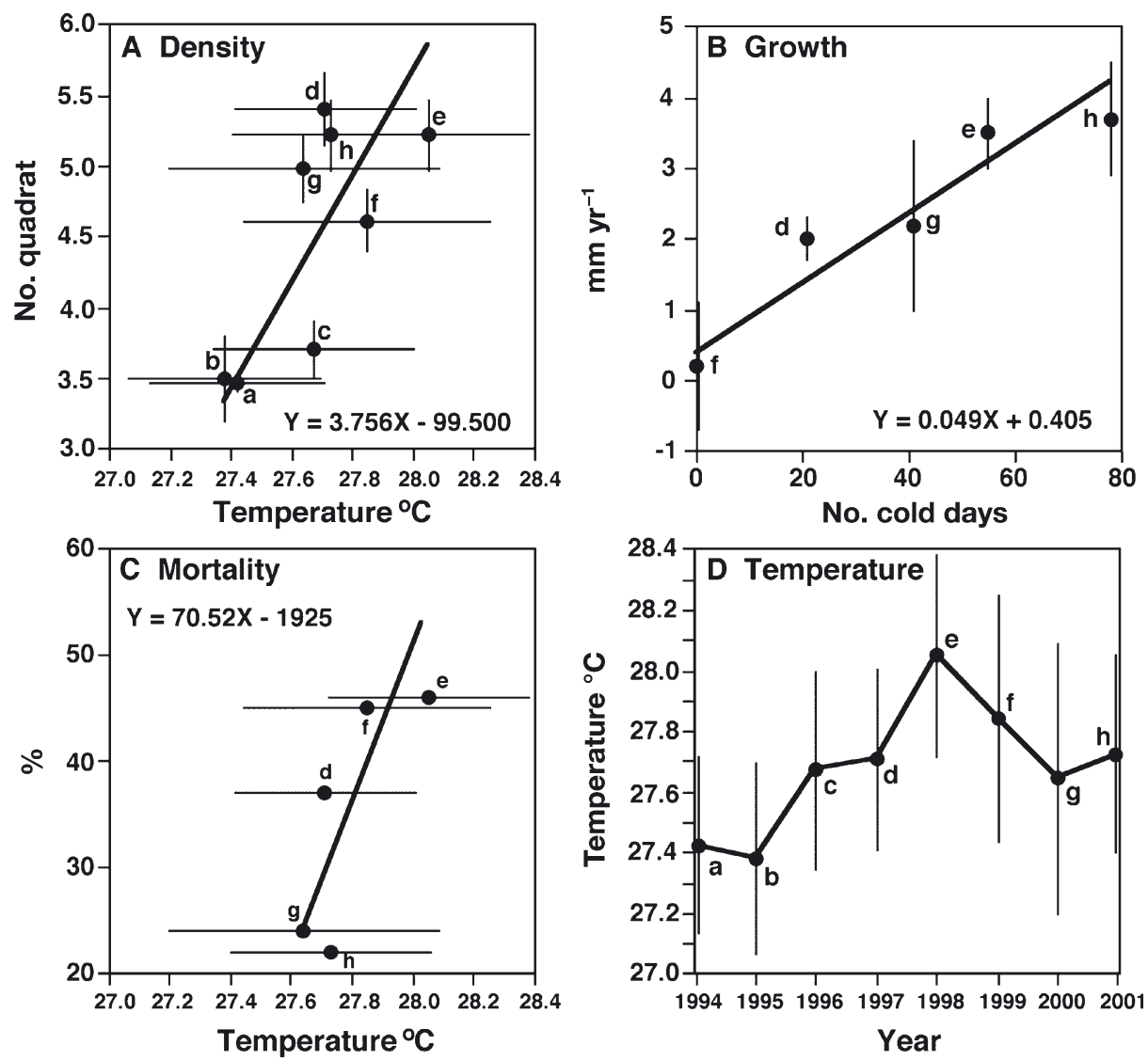

Fig. 3. Scatter-plots of relationships between dynamics of juvenile coral population in St. John (pooled by genus and site) and seawater temperature. Lower-case letters are sampling years in (D); Model II regression lines and their equations are displayed in (A) through (C). (A) Density of corals (no. $0.25 \mathrm{~m}^{-2}$ quadrat) between 1994 and 2001 versus yearly mean monthly temperature in year preceding measurement; density was correlated significantly with temperature; means \pm SE (density: $\mathrm{n}=200$ to 240 except for 1995 where $\mathrm{n}=80$; temperature; $\mathrm{n}=12$ ). (B) Growth rate $\left(\mathrm{mm} \mathrm{yr}^{-1}\right)$ versus number of cold days in 12 to 24 mo period prior to measurement of growth; growth was correlated significantly and positively with number of cold days; measurements were made between 1996 and 2001, and are shown as means \pm SE, with following sample sizes: 1997, $\mathrm{n}=248 ; 1998, \mathrm{n}=100 ; 1999$, $\mathrm{n}=59$; $2000, n=22 ; 2001, n=38$. (C) Annual mortality rate (\%) versus yearly mean monthly temperature in year preceding measurement; sample sizes (number of tagged corals whose fate could be determined after 1 yr) were 394 corals in 1997, 185 in 1998, 108 in 1999, 29 in 2000, and 49 in 2001; mortality was positively, but non-significantly correlated with temperature. (D) Mean monthly seawater temperature for 12 mo preceding each sampling (for example, August to August); these values differ from yearly mean monthly temperatures by calendar year in Fig. 2A. Time periods a to c are not given in (B) and (C) because corals were first tagged in 1996 to provide growth and mortality data starting in 1997

few extreme days, 3 yr (1997 to 1999) with a large number of hot $\left(>29.3^{\circ} \mathrm{C}\right)$ days, and 1 yr (2000) with a relatively large number of cold days (Fig. 2B).

\section{DISCUSSION}

This study shows that the seawater temperature in St. John, US Virgin Islands, has increased rapidly, with annual variations that are tracked closely by the population dynamics of juvenile corals. After more than a decade of an upward thermal trend, the relative abundance of juvenile coral genera has shifted significantly in favor of Siderastrea over Porites, Agaricia and Favia.
In contrast to the striking changes in coral reef community-structure that follow severe bleaching (HoeghGuldberg 1999, Knowlton 2001), this study has demonstrated that gradually rising seawater temperature is associated with changes in coral populations that appear to be caused by enhanced recruitment and depressed growth rates associated with higher mean temperature and a reduction in the number of cold days, respectively. Because these expressions of thermal sensitivity probably vary among coral species (Coles \& Jokiel 1977, Loya et al. 2001), potentially they could drive the observed changes in relative abundance of coral genera (Fig. 4). Together, these findings are important because they are among the first to 


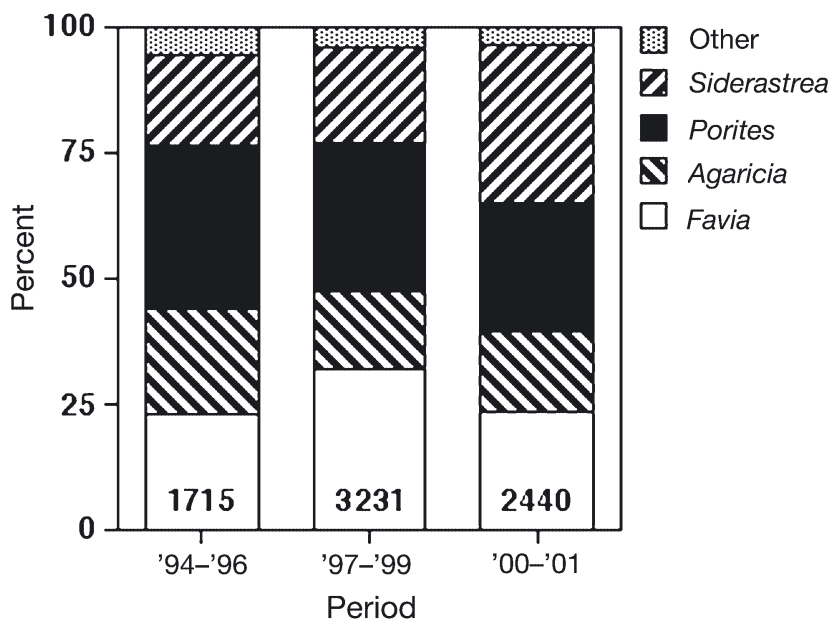

Fig. 4. Generic composition of juvenile coral population over 3 periods of either 3 yr (1994-1996 and 1997-1999) or 2 yr (2000-2001) duration; percentages are shown with sample sizes in each bar. Abundances are pooled by site, and rare genera ('Other') have been pooled (the 4 named genera accounted for $\geq 96 \%$ of the corals). The relative abundance of each taxon varied significantly among the 3 periods, largely because Favia was abundant in 1997-1998, while Siderastrea was rare in 1994-1996 but common in 1997-1999 and (especially) 2000-2001 (see 'Results' for further details)

describe the inconspicuous changes in coral community structure that can be expected as the grip of global climate change tightens. Such changes might easily go unnoticed amid the growing reports of striking reef loss (Hoegh-Guldberg 1999, Knowlton 2001), yet they could have profound effects by altering the relative abundance of functionally important corals such as reef-building species or those with a high degree of physiological resilience.

The trend for seawater warming in St. John is $\approx 10$ times faster than the increase in global surface average temperature (IPCC 2001), but is similar to the $0.7^{\circ} \mathrm{C}$ increase recorded at $3 \mathrm{~m}$ depth in La Parguera, Puerto Rico, between 1966 and 1995 (Winter et al. 1998). The steepest portion of the warming trend in La Parguera occurred at roughly the same time (1986 to 1995: Winter et al. 1998) that rapid warming was recorded in St. John, demonstrating that a generalized warming trend has occurred in at least 2 locations in the northeastern Caribbean. Hot-spots of seawater warming are characteristic of the heterogeneous trend of global warming (Winter et al. 1998, Helmuth et al. 2002, Walther et al. 2002), and in Great Lameshur Bay slow flow-speeds $\left(<5 \mathrm{~cm} \mathrm{~s}^{-1}\right)$ and long residency times (ca. $12 \mathrm{~h}$ ) for seawater in the shallow bay (P. J. Edmunds, unpubl. data) favor accelerated warming. The present results suggest that both the increase in mean temperature-correlated with juvenile density - and the changing frequency of thermally extreme days - correlated with growth - have important consequences for juvenile corals.

The positive association between temperature and juvenile coral population dynamics contradicts the well-known negative effects of high temperature on corals (Szmant \& Gassman 1990, Hoegh-Guldberg 1999, Edmunds et al. 2001), but the apparent discrepancy can be explained by the characteristics of the thermal regime recorded in the shallow waters of St. John and the coral life-stages investigated. Seawater temperature has increased rapidly in St. John, but it has not included upward thermal spikes of the magnitude or duration necessary to cause wide-scale coral mortality by bleaching (Hoegh-Guldberg 1999, Edmunds 2000, Berkelmans 2002). The number of hot days per year increased significantly during the course of this study, but the absence of a significant association with juvenile coral dynamics suggest that such days may still be too rare and insufficiently extreme to have a measurable effect. Instead of killing corals directly, the net effect of gradually rising temperatures on juvenile corals reflects the summation of both positive and negative proximal effects that are probably complex and interconnected. Without experimentally testing the importance of each of these effects, it is difficult to predict the consequences of rising temperature for coral populations, and equally challenging to determine the fundamental causes of empirical relationships such as those reported here (i.e. between temperature and juvenile corals). Such challenges are intensified by the inability to predict where in the environmental thermal stress will be most acute (Helmuth et al. 2002), or which aspect of the thermal regime has the strongest biological effects. For example, the results of this study suggest that the important effects of temperature on juvenile corals are realized in part through linear changes in the yearly mean monthly values (Fig. 2A), the number of cold days per year (Fig. 2B), or perhaps through a threshold effect, as suggested by the separation of the density data for 1994 to 1996 from those for 1997 to 2001 (Fig. 3A). Nevertheless, other than revealing simply that high temperatures ultimately have detrimental consequences for juvenile corals by impairing growth and perhaps increasing mortality (Fig. 3), the present results can be used to posit a variety of mechanisms through which temperature could play a pivotal role in structuring populations of juvenile corals. Of these, 2 are worthy of closer experimental scrutiny because of their explanatory power and consistency with other studies. One alternative explanation for the present results - that the dynamics of juvenile corals in St. John between 1996 and 2000 were mediated by hurricane damage cannot be evaluated with the available data because 
they span a period when only 2 intense hurricanes ('Luis' and 'Marilyn', both in 1995) impacted St. John. First, high temperature could enhance the metamorphosis of coral larvae. Elevated temperatures typically accelerate larval development in marine invertebrates (Hoegh-Guldberg \& Pearse 1995) and fishes (Meekan et al. 2003); for benthic taxa this can result in a shorter planktonic phase. The prediction that coral larvae also metamorphose sooner at higher temperatures has been supported experimentally with larvae from the Caribbean coral Porites astreoides (Edmunds et al. 2001) and, indirectly, by evidence that corals recruit more heavily in the thermal plume of power plants (Coles 1985). If elevated temperatures have a direct stimulatory effect on the development of coral larvae (Ball et al. 2002), then the increased density of juvenile corals in warmer years could result from accelerated metamorphosis of coral larvae and their settlement before they are carried away by water flow from the study reefs. Although an increased density of juvenile corals could also be created by enhanced larval supply, this possibility is made less likely by the inhibitory effect of temperatures on coral fecundity (Szmant \& Gassman 1990) and its null or inhibitory effects on fertilization success (Omori et al. 2001, Bassim et al. 2002).

Second, wintertime tissue-conditioning could enhance juvenile coral success. Faced with evidence that corals thicken their tissues during the winter and spring (Brown et al. 1999, Fitt et al. 2000), and increase their photosynthetic capacity (Warner et al. 2002), it is tempting to suggest that similar events underlie the positive correlation between growth and the number of cold days 12 to 24 mo prior to the measurement of growth. This hypothesis requires that juvenile corals undergo wintertime tissue-thickening similar to that in adults (Brown et al. 1999, Fitt et al. 2000), and that thick tissues ultimately confer a growth advantage. Because the growth of juvenile corals in the present study is correlated with the number of cold days 12 to 24 mo prior to measurement (and not in the year preceding measurement), the putative growth advantage of a cold winter would have to be realized no sooner than the autumn of the following year in order to create a 1 yr lag-effect in the association between growth and the number of cold days. Interestingly, the highest seawater temperature in St. John typically occurs in the late summer and early autumn (Fig. 2A; P. J. Edmunds unpubl. data), so that any energetic costs associated with this thermal stress in juvenile corals would probably be met from reserves accumulated over the previous 12 mo. However, any putative growth advantages of resisting this late-season thermal stress would not be recorded with the present sampling regime until the following summer (i.e. within a 12 to 24 mo window following the establishment of the pertinent resources represented by thicker tissue). Since the average tagged juvenile coral was $16.3 \mathrm{~mm}$ diameter, with a growth rate of $12 \mathrm{~mm} \mathrm{y}^{-1}$ (Bak \& Engel 1979, VanMoorsel 1988) they would be old enough $(\approx 16 \mathrm{mo})$ to potentially have been affected by the thermal regime 12 to 24 mo prior to measurement. As the number of cold days declines, the associated reduction in growth rates would ensure that juvenile corals remain small for a longer period, thereby increasing their exposure to size-dependent mortality (Jackson 1977) and contributing to the elevated mortality tentatively associated with warm water. The growth rates in the present study (Fig. 3B) suggest that the juvenile corals are older than $16 \mathrm{mo}$, but the age estimates based on these rates ( $\geq 4 \mathrm{yr}$ ) are inconsistent with the high chance of dying each year (22 to $46 \%$ ), and the size of recruits $(\approx 10 \mathrm{~mm})$ that appeared between the 12 mo sampling intervals (P. J. Edmunds pers. obs.). Together with the significant inverse correlation between colony size and growth rate $(p=0.001$, data not shown), these discrepancies suggest that the slow annual growth rates of average-sized juvenile corals in St. John may reflect the inhibitory effects of competition between their expanding borders and algal turf on the adjacent substratum.

Regardless of the proximal causes of the effects of increasing temperature on juvenile corals, the end result is a change in the relative abundance of coral genera. The most parsimonious explanation for these taxonomic trends is that temperature affects different taxa in dissimilar ways, according to their resilience to thermal stress (Coles \& Jokiel 1977, Loya et al. 2001). Both of the increases in juvenile coral abundance over this period - for Favia over 1997/1999, and Siderastrea over 2000/2001 - involve species that are characteristic of shallow water and disturbed habitats. In comparison to the other dominant taxa (Fig. 4), F. fragum is the only species that combines a short life-span and yearround reproduction (Fadlallah 1983, Szmant 1986, Soong 1991) (members of the other dominant taxa also release larvae year-round), and therefore might be able to increase in abundance during thermal stress by recruiting throughout the year. The increase in Siderastrea) caused largely by $S$. radians, which accounted for $>79 \%$ of the Siderastrea) toward the end of a $12 \mathrm{yr}$ warming trend might be a result of the unusual taxon of symbiotic zooxanthellae found in $S$. radians (Type 'B5a': LaJeunesse 2002) and their tolerance of temperatures as high as $36^{\circ} \mathrm{C}$ (Warner et al. 1996).

The present results for juvenile corals in St. John reveal subtle taxonomic perturbations that are associated with gradually rising seawater temperature. Interestingly, recent work from southern New England has 
also demonstrated subtle effects of rising seawater temperature on sessile marine invertebrates (Stachowicz et al. 2002), in this case with the ecologically importance consequence of facilitating invasion by nonindigenous species. Similar to the results of the present study (Fig. 3) the population dynamics of invertebrates in southern New England were related to both mean and extreme (high) seawater temperatures (Stachowicz et al. 2002). For juvenile coral populations in St. John, it is too early to tell whether the changes associated with the upward trend in seawater temperature have long-term ecological significance, but the increasing abundance of corals that produce small and morphologically simple colonies (Favia fragum and Siderastrea radians) at the expense of those that produce larger and more complex colonies (e.g. Porites furcata and $P$. astreoides) is cause for concern, for example in terms of reef accretion and the creation of habitat for other taxa. Although the immediate effects of these changes pale into insignificance in the face of some of the striking impacts of global warming, these subtle changes may have far-reaching ecological consequences if they foreshadow changes in ecosystem function such as the loss of resiliency that paves the way for phase-shifts in species composition (Scheffer et al. 2001).

Acknowledgements. I would like to thank C. S. Rogers for the support that made this study possible, and J. D. Witman for inspiration in ecological monitoring. This research would have been impossible without the NPS/USGS temperature records for Great Lameshur Bay made available by J. Miller, C. S. Rogers and D. Catenzaro. Major funding was provided by the Reef Assessment as well as the Inventory and Monitoring programs of the National Park Service, California State University, Northridge and, in part, a grant from the Sea Grant Program of the University of Puerto Rico (\#R-101-2-02). I would like to thank E. D. Keach and my graduate students for field assistance, S. Prosterman for SCUBA support, and the staff of the Virgin Islands Ecological Resource Station for hosting our visits. Comments from J. F. Bruno, R. C. Carpenter, S. Dudgeon, R. D. Gates and 4 anonymous reviewers improved earlier drafts of this paper. This is contribution 120 of the CSUN Marine Biology Program.

\section{LITERATURE CITED}

Bak RPM, Engel MS (1979) Distribution, abundance and survival of juvenile hermatypic corals (Scleractinia) and the importance of life history strategies in the parent community. Mar Biol 54:341-352

Ball EE, Hayward DC, Reece-Hoyes JS, Hislop NR, Samuel G, Saint R, Harrison PL, Miller DJ (2002) Coral development: from classical embryology to molecular control. Int J Dev Biol 46:671-678

Bassim KM, Sammarco PW, Snell TL (2002) Effects of temperature on success of (self and non self) fertilization and embryogenesis in Diploria strigosa (Cnidaria, Scleractinia). Mar Biol 140:479-488
Berkelmans R (2002) Time-integrated thermal bleaching thresholds of reefs and their variation on the Great Barrier Reef. Mar Ecol Prog Ser 229:73-82

Brown BE, Dunne RP, Ambarsari I, LeTissier MDA, Satapoomin U (1999) Seasonal fluctuations in environmental factors and variations in symbiotic algae and chlorophyll pigments in four Indo-Pacific coral species. Mar Ecol Prog Ser 191:53-69

Buddemeier RW, Kinzie RA (1976) Coral growth. Oceanogr Mar Biol Annu Rev 14:183-225

Coles SL (1985) The effects of elevated temperature on reef coral planulae settlement as related to power plant entrainment. Proc 5th Int Coral Reef Congr 4:171-176

Coles SL, Jokiel PL (1977) Effects of temperature on photosynthesis and respiration in hermatypic corals. Mar Biol 43:209-216

Edmunds PJ (2000) Patterns in the distribution of juvenile corals and coral reef community structure in St. John, US Virgin Islands. Mar Ecol Prog Ser 202:113-124

Edmunds PJ (2002) Long-term dynamics of coral reefs in St. John, US Virgin Islands. Coral Reefs 21:357-367

Edmunds PJ, Gates RD, Gleason DF (2001) The biology of larvae from the reef coral Porites astreoides, and their response to temperature disturbances. Mar Biol 139: 981-989

Fadlallah YH (1983) Sexual reproduction, development and larval biology in scleractinian corals. Coral Reefs 2: $129-150$

Fitt WK, McFarland FK, Warner ME, Chilcoat GC (2000) Seasonal patterns of tissue biomass and densities of symbiotic dinoflagellates in reef corals and relation to coral bleaching. Limnol Oceanogr 45:677-685

Fitt WK, Brown BE, Warner ME, Dunne RP (2001) Coral bleaching: interpretation of thermal tolerance limits and thermal thresholds in tropical corals. Coral Reefs 20:51-65

Fong P, Glynn PW (2000) A regional model to predict coral population dynamics in response to El Niño-Southern oscillations. Ecol Appl 10:842-854

Harrison PL, Wallace CC (1990) Reproduction, dispersal and recruitment of scleractinian corals. In: Dubinsky Z (ed) Ecosystems of the world. Vol 25, Coral reefs. Elsevier, New York, p 133-207

Helmuth B, Harley CDG, Halpin PM, O'Donnell M, Hofmann GE, Blanchette CA (2002) Climate change and latitudinal patterns of intertidal thermal stress. Science 298: 1015-1017

Hoegh-Guldberg O (1999) Climate change, coral bleaching and the future of the world's coral reefs. Mar Freshw Res 50:839-866

Hoegh-Guldberg O, Pearse JS (1995) Temperature, food availability, and the development of marine invertebrate larvae. Am Zool 35:415-425

IPCC (Intergovernmental Panel on Climate Change) (2001) Third assessment report of the intergovernmental panel on climate change IPCC (WGI \& II). Cambridge University Press, Cambridge

Jackson JBC (1977) Competition on marine hard substrata: the adaptive significance of solitary and colonial strategies. Am Nat 111:743-766

Knowlton N (2001) The future of coral reefs. Proc Natl Acad Sci USA 98:5419-5425

LaJeunesse TC (2002) Diversity and community structure of symbiotic dinoflagellates from Caribbean coral reefs. Mar Biol 141:387-400

Loya Y, Sakai K, Yamazato K, Nakano Y, Sambali H, vanWoesik R (2001) Coral bleaching: the winners and losers. Ecol Lett 4:122-131 
Meekan MG, Carleton JH, McKinnon AD, Flynn K, Furnas M (2003) What determines the growth of tropical fish larvae in the plankton: food or temperature? Mar Ecol Prog Ser 256:193-204

Omori M, Fukami H, Kobinata H, Hatta M (2001) Significant drop of fertilization of Acropora corals in 1999: an aftereffect of heavy coral bleaching? Limonol Oceanogr 46: 704-706

Rogers CS, Beets J (2001) Degradation of marine ecosystems and decline of fishery resources in marine protected areas in the US Virgin Islands. Environ Conserv 28:312-322

Rogers CS, Miller J (2001) Coral bleaching, hurricane damage, and benthic cover on coral reefs in St. John, U.S. Virgin Islands: a comparison of surveys with the chain transect method and videography. Bull Mar Sci 69:459-470

Scheffer M, Carpenter S, Foley JA, Folke C, Walker B (2001) Catastrophic shifts in ecosystems. Nature 413:591-596

Soong K (1991) Sexual reproductive patterns of shallowwater reef corals in Panama. Bull Mar Sci 49:832-846

Stachowicz JJ, Terwin JR, Whitlach RB, Osman RW (2002) Linking climate change and biological invasions: ocean warming facilitates nonindigenous species invasions. Proc Natl Acad Sci USA 99:15497-15500

Szmant AM (1986) Reproductive ecology of Caribbean reef corals. Coral Reefs 5:43-54

Szmant AM, Gassman NJ (1990) The effects of prolonged 'bleaching' on the tissue biomass and reproduction of the reef coral Montastrea annularis. Coral Reefs 8:217-224

Editorial responsibility: Charles Birkeland

Honolulu, Hawaii, USA
Tamelander J (2002) Coral recruitment following a mass mortality event. Ambio 31:551-557

VanMoorsel GWMN (1988) Early maximum growth of stony corals (Scleractinian) after settlement of artificial substrata on a Caribbean reef. Mar Ecol Prog Ser 50:127-135

Walther GR, Post E, Convey P, Menzel A and 5 others (2002) Ecological responses to recent climate change. Nature 416:389-395

Warner ME, Fitt WK, Schmidt GW (1996) The effects of elevated temperature on the photosynthetic efficiency of zooxanthellae in hospite from four different species of reef corals: a novel approach. Plant Cell Environ 19:291-299

Warner ME, Fitt WK, Schmidt GW (1999) Damage to photosystem II in symbiotic dinoflagellates: a determinant of coral bleaching. Proc Natl Acad Sci USA 96:8007-8012

Warner ME, Chilcoat GC, McFarland FK, Fitt WK (2002) Seasonal fluctuations in the photosynthetic capacity of photosystem II in symbiotic dinoflagellates in the Caribbean reef-building coral Montastraea. Mar Biol 141:31-38

Winter A, Appeldorn RS, Bruckner A, Williams EH, Goenaga C (1998) Sea surface temperatures and coral reef bleaching off La Parguera, Puerto Rico (northeastern Caribbean Sea). Coral Reefs 17:377-382

Witman JD (1992) Physical disturbances and community structure of exposed and protected reefs: a case study from St. John, U.S. Virgin Islands. Am Zool 32:641-654

Zar JH (1999) Biostatistical analysis, 4th edn. Prentice-Hall, Upper Saddle River, NJ

Submitted: January 3, 2002; Accepted: October 17, 2003

Proofs received from author(s): March 17, 2004 